Meta

Journal des traducteurs

Translators' Journal

\title{
Evaluations - a Key Towards Understanding the Affective Dimension of Translational Decisions
}

\section{Sonja Tirkkonen-Condit et Johanna Laukkanen}

Volume 41, numéro 1, mars 1996

Le(s) processus de traduction / Translation Process(es)

URI : https://id.erudit.org/iderudit/002360ar

DOI : https://doi.org/10.7202/002360ar

Aller au sommaire du numéro

Éditeur(s)

Les Presses de l'Université de Montréal

ISSN

0026-0452 (imprimé)

1492-1421 (numérique)

Découvrir la revue

Citer cet article

Tirkkonen-Condit, S. \& Laukkanen, J. (1996). Evaluations — a Key Towards Understanding the Affective Dimension of Translational Decisions. Meta, 41(1), 45-59. https://doi.org/10.7202/002360ar
Résumé de l'article

Afin d'en savoir plus sur l'aspect affectif des décisions prises par les traducteurs en situation de travail, on tente de cerner l'image qu'ils se font d'eux-mêmes, et de mettre à jour leur théorie personnelle de la traduction. Pour ce faire, les auteurs ont effectué une analyse des éléments expressifs de traducteurs professionnels soumis à une étude dans laquelle ils devaient traduire tout en exprimant leurs pensées à haute voix. Les théories personnelles ont été déduites des évaluations exprimées lors d'une prise de décision entre deux solutions de traduction, et les données sur la perception que les traducteurs ont d'eux-mêmes viennent de commentaires touchant iexécution de la tâche elle-même. Les auteurs croient que le processus de prise de décision durant la traduction dépend fortement de ces deux facteurs. 


\title{
EVALUATIONS - A KEY TOWARDS UNDERSTANDING THE AFFECTIVE DIMENSION OF TRANSLATIONAL DECISIONS
}

\author{
SONJA TIRKKONEN-CONDIT AND JOHANNA LAUKKANEN \\ University of Joensuu, Joensuu, Finland
}

\begin{abstract}
Résumé
Afin d'en savoir plus sur l'aspect affectif des décisions prises par les traducteurs en situation de travail, on tente de cerner l'image qu'ils se font d'eux-mêmes, et de mettre à jour leur théorie personnelle de la traduction. Pour ce faire, les auteurs ont effectué une analyse des éléments expressifs de traducteurs professionnels soumis à une étude dans laquelle ils devaient traduire tout en exprimant leurs pensées à haute voix. Les théories personnelles ont été déduites des évaluations exprimées lors d'une prise de décision entre deux solutions de traduction, et les données sur la perception que les traducteurs ont d'euxmêmes viennent de commentaires touchant l'exécution de la tâche elle-même. Les auteurs croient que le processus de prise de décision durant la traduction dépend fortement de ces deux facteurs.
\end{abstract}

\begin{abstract}
An analysis was done of the evaluative expressions which appeared in the think-aloud data derived from two sets of experiments on professional translators. The aim was to shed light on the affective side of translators' decisions by identifying their professional self. image and their subjective theories of translation. The theories were inferred from evaluations voiced at decision points between translation variants, whereas ideas about the self were inferred from statements concerning task performance and, in one instance, concerning the translator himself. It is presumed that the translators' decision-making throughout the process largely depends on these two factors.
\end{abstract}

\section{THE PURPOSE OF THE STUDY}

Empirical research on translation processes indicates that the right affective frame of mind goes together with creativity and success in translation (Kussmaul 1991; Jääskeläinen 1990; Laukkanen 1993; Tirkkonen-Condit 1992). Also, translation is being recognized as a decision-making process (Mossop 1983; Lefevere 1992; Wilss 1993; Tirkkonen-Condit 1990), and decision-making in turn is currently understood as being directed by affect rather than rationality (Etzioni 1988 and Schwenk 1984). Thus affect deserves particular attention in empirical translation research.

Protocol analysis has turned out to be a fruitful method for seeking information about the affective side of professional translators' work. Attitudes and motivation as well as individual translation strategies, decision criteria, and what we have called, inspired by the ideas suggested by Mossop (1983: 249) and Königs (1991: 137), subjective theories of translation, have been explored by this method. The subjective theories determine how the job is done, so that knowledge about these theories bears on translation quality as well. If the translator sees herself as merely a text-processor, she concentrates on finding "equivalents" for what is in the text. If, however, she sees herself as a writer who reports 
the relevant dimensions of the original communication to her addressees, she then takes a full responsibility for designing the target text in such a manner that it makes sense to the addressee.

Our analysis of evaluative statements in professional translators' think-aloud protocols enabled us to get a glimpse at subjective theories. The evaluations revealed how the individual translators pictured the target text they were producing and why they ended up at particular translational choices. This is the kind of knowledge which, for example, House (1988: 89) seemed to be missing, as she deplored the poverty of the think-aloud data derived from language students. ${ }^{1}$

Our analysis of evaluative statements also emerged as a useful method of seeking information about the translators' attitudes and professional self-image. The purpose of the present article is to show how the study of evaluations can shed light on what we think are major factors behind translational decisions, namely (i) the translators' professional self-image and (ii) the translators' subjective theories of translation.

\section{BACKGROUND TO THE STUDY OF EVALUATIONS}

Our systematic study of evaluations first started, when the verbalisations elicited in Laukkanen's study on a professional translator's routine vs. non-routine processes were subjected to attention unit analysis (for a description of the attention unit analysis see Jääskeläinen in this volume): it turned out that a number of evaluations did not fit any of the categories but seemed to fall outside as residual items. Laukkanen then decided to analyse all the evaluations in her data separately. The outcome of the evaluation analysis was a clearer picture of the subject's affective profile and self-image in the two different tasks, which in turn helped the analyst to account for the qualitative difference in the products. A fuller account of this experiment is given below in point 2.1. (see also Laukkanen 1993 and in press).

Evaluation analysis was subsequently applied to the data elicited in a think-aloud experiment administered by Tirkkonen-Condit on three teachers of translation, two of whom also worked as professional freelance translators. The experimental task was a non-routine task for all the three subjects. This analysis also yielded information about the translators' professional self-image, but the emphasis was on what has been referred to as subjective theories of translation, i.e. information about how the translators pictured the task and the qualities and features in the target text they were producing. An account of this experiment is given below in point 2.2 .

The evaluative statements identified in our data were classified according to the object of evaluation. There were evaluations relating to the source text and the translation task, aspects of the working process, such as the use of translation aids, the translator himself and, finally, instances of variant choice. The last category turned out to be a rich source of information concerning the translators' ideas of what it was that they were aiming at, i.e. their subjective theories of translation.

\subsection{Laukkanen's Experiment}

There was one subject in the experiment. She was a certified translator who has worked as a freelance translator of travel brochures for several years. The subject was to perform two translation tasks, a routine task and a non-routine one. The routine text was a part of a travel brochure on Eastern Finland, which was to be translated into English, i.e. from the subject's mother tongue into a foreign language. Eastern Finland is an area which the subject knows very well, as she lives there herself and her translation work has also focussed on brochures dealing with that area. The English-language version of the brochure was meant mainly for the use of Tourist Information Offices, where it was to be 
distributed, together with the Finnish and Swedish versions of the same brochure. It was not to be translated into other languages, because the tourists from Central Europe, for example, were expected to read the English version. The source text comprises 168 words and its English translation 252 words (see Appendix 1 for the translation).

The non-routine text was a chewing gum advertisement which was also to be translated from Finnish into English. The advertisement was to appear in a magazine titled Welcome to Finland. This magazine is published by Finnair, and it is distributed free of charge in airports and on Finnair's planes. The subject was given a free hand to plan and edit the target text; the only limitation was that the target text was not to be longer than the Finnish source text. The source text comprises 65 words and its translation 95 words (see Appendix 2 for the translation).

The subject was asked to translate from Finnish into English because this was the way she normally worked. There was no time limit, and the subject was allowed to return to the task the following day to make revisions. The subject had dictionaries and other background material such as travel brochures and magazines at her disposal, and she worked with a word processor.

The subject verbalised her thoughts fluently during the four sessions; she also pointed out herself that she was used to thinking aloud while working. She spent 97 minutes in the first session and 14 minutes in the second session of the routine task. The time spent in the first session of the non-routine task was 89 minutes and in the second session 8 minutes. The subject of this experiment will be referred to with the fictional name Leena.

\subsection{Tirkkonen-Condit's Experiment}

The source text in this experiment was an editorial of the Helsingin Sanomat of Sunday 27th October 1991. It had the title "Kilpailu on pakko oppia" (Competition must be learned) and, as the title suggests, it took a favourable stand to the more stringent laws on competitive practices which were being introduced in Finland at the time. The task was to translate the text, except for the first two paragraphs, into English, assuming that the translation of the entire text would be used as a sample text in a research report on the argumentation styles of Finnish editorials. This was a realistic task, because the text belonged to a corpus of Finnish editorials which had been analysed for a comparative study on argumentation only a couple of months earlier. The experimenter's own translation of the text, with a short summary of the first two paragraphs (which were not to be translated in the experiment), is given in Appendix 3. It comprises about 400 words.

There were three subjects who were teachers of English and translation; one was a native speaker of English, while the other two were native speakers of Finnish, who also did professional freelance translation into English. The fictional names of the subjects will be Francis, Hanna and Kari. The subjects were instructed to think aloud while translating, and the sessions were tape-recorded in their entirety. The experiment took place in each subject's own office, with access to translation aids and a word processor. There was no time limit, and the time spent varied from 1.5 to 2.5 hours. None of the subjects had trouble in verbalising their thoughts, although there were individual differences in the amount and density of verbalisation. In fact Francis and Hanna said that thinking aloud while translating belonged to their normal working routine. Kari said that he normally talks to himself silently when he translates.

What follows is an account of the translators' self-image and their subjective theories of translation, as revealed by our analysis of the evaluative expressions elicited by the two sets of experiments described above. 


\section{TOWARDS UNDERSTANDING TRANSLATORS' SELF-IMAGE}

The evaluations found in Leena's protocols revealed differences in her attitudes and conceptions of herself as a translator in the two tasks. In general it can be said that she was more self-confident and secure in the routine process. This affective difference manifested itself, for example, in that Leena expressed more evaluations of tentative translation variants in the non-routine process, i.e. she hesitated more before she made her choice. Secondly, Leena had a more critical attitude towards the routine source text, whereas she did not seem to feel 'entitled' to criticize the non-routine source text. Thus there were no negative evaluations of the non-routine source text. Below are some examples of the ways in which Leena criticised the routine text, i.e. the brochure on Eastern Finland:

(1) tää on niin pöhkö (.) tyypillinen pöhkö otsake näissä

[this is such a silly (.) a typical silly title in these]

(2) täss ei oo semmosta (.) sidoksisuutta jotenki koko tekstissä (.) täss suomenkielisessä

[there is no (.) coherence at all in this text somehow (.) in the Finnish text]

(3) tää ei jotenki emmä tiiä tää ei tää otsikko ei mun mielestä istu tähän niinku

[this doesn't somehow I don't know I don't think this title fits here]

(4) mut toisaalta mä kyllä vieläkii protestoin tota oopperaa vastaa et mitä varte se on pantu tähän (.) mitä varte ne nyt mainostaa itteensä oopperalla kun ne nyt on kuitenki Sulkavalla

[but on the other hand I still do protest against the opera here why on earth have they put it in here (.) why do they advertise themselves with the opera now although they are in Sulkava]

Additionally, Leena criticized the routine ST indirectly by expressing opinions about the style in travel brochures in general:

(5) nää on taas näitä (.) supisuomalaisia keksintöjä (.) nää viihderavintolat elikkä tää on ravintola jossa on tanssia iltasin (4.0) amm nää on kamalan vaikeita kääntää aina englanniks

[here's again one of these (.) thoroughly Finnish inventions (.) this restaurant of entertainment which means that it's a restaurant with dance music in the evenings (4.0) umm these are always terribly difficult to translate into English]

(6) oman lisänsä lomaasi nää on niin tyypillisiä jaarituksia näissä (.) ei näitä oikein voi kääntää suoraan

[additional activity for your holiday this is just so typical nonsense in these (.) you can't really translate it directly]

(7) jaa täss on kolme pistettä sitte perää emmä tiiä tää nyt on vähän pöhköö

[well then there are three dots at the end I don't know this is a bit silly]

Her critical attitude towards the ST in the routine task in turn led Leena to edit her translation more and to make improvements in the text. Consequently, the routine process was somewhat more successful than the non-routine process. The final versions of the translations were assessed by a native speaker of English, who teaches translation and has plenty of experience in revising translations. In his opinion the routine target text could have been published as such, whereas the non-routine target text contained stylistic mistakes and needed editing before being published. Somewhat surprisingly, Leena's approach to the non-routine task was conservative: she made an attempt to write an English text which would serve as an "equivalent" of the text in the Finnish advertisement, although she was given a free hand to design the advertisement as she pleased.

One manifestation of Leena's insecurity in the advertisement task was that she seemed to encourage herself on several occasions by expressing positive evaluations of the produced translation. Furthermore, she seemed to rely more on the background material, i.e. the magazines etc., where she found appropriate expressions that might also be usable in her translation: 
(8) tossa artikkelissa oli sanottu iha (.) aika jännästi se juttu tuolla (2.0) [WF] se oli singled out (.) muistaakseni

[in this article they had put it quite (.) quite nicely that thing there (2.0) [WF] it was SINGLED OUT (.) if I remember correctly]

(9) tuoss on kyllä ihan ideaa tuossa in (1.0) in Finland Sweden Norway and Iceland [it's a rather good idea this IN (1.0) IN FINLAND SWEDEN NORWAY AND ICELAND]

(10) tuo onkii aika hyvin (.) hyvin sanottu tuokin (.) chewing gum is the confection with the best sales figures in Finland

[this is quite well (.) well said too (.) CHEWING GUM IS THE CONFECTION WITH THE BEST SALES FIGURES IN FINLAND]

The nature of problems in the two tasks was also different: Leena reacted rather calmly to the difficulties in the routine process and often mentioned that she had solved similar problems dozens of times before, whereas in the non-routine process her attitude was more negative and insecure and she needed more time for solving the problems. Examples of the problematic points in the routine process are given below:

(11) mut se laituri o hankala (1.0) oikeestaan se on jetty semmonen veneille ja pienille nää nyt ei hirveen isoja laitureita voi olla

[but this laituri (quay) is a tricky one (1.0) actually it is JETTY something meant for boats and small vessels these here can't be that big quays]

(12) tää on than hassu lause ku pitäs ensin niiku (.) se o-(.) pitäs tietää että mitä on kirkkoveneet ja miten ne kulkee ja (.) normaalisti ja miten ne sitten voi kulkee tälläsessä (.) hurjassa kilpailussa (.) ja nää on kaikki semmosia asioita mitä ei (.) välttämättä tiedä mut toisaalta kyllä englantilaiset tietää long-boats kun siell on ne Cambridgen ja (.) Oxfordin soutukilpailut ne nyt on ihan erilaisii veneitä mut ajatus on sama (3.0) joo tää pitää kyllä pistää ne kuitenkii selittäă vähä et ne on tämmösii perinteisii (.) perinteisii kirkkoveneitä niiku mä oon tehny aikasemminkin

[this is really a silly sentence because first they should (.) it $\mathrm{i}-($.$) they should know what$ church-boats are and how they move and (.) normally and how they move in this kind of (.) wild competition (.) and these are all such things that people don't (.) necessarily know but on the other hand Englishmen do know LONG-BOATS as they have this Cambridge and Oxford rowing-match they are of course quite different boats but it's the same idea (3.0) yeah this must be added it must be somehow explained that they are kind of traditional (.) traditional church-boats like I've done before]

(13) Sulkava Holiday Centre (1.0) tuo on vieläkin semmone vähä hölmö juttu että pistäskö sen suomeks vai pistäskö sen englanniks se rïppus nyt toimeksantajasta mite se haluu ku täss ois tietysti varmaan kahdenlaista käytäntöö

[SULKAVA HOLIDAY CENTRE (1.0) this is still a little bit problematic I wonder if I should put this in Finnish or in English it would depend on the employer and his wishes because there are of course two ways of doing it]

The problems in the travel brochure task were quite easily solved and Leena did not need much time for dealing with them. In many cases she first mentioned the difficulty and explained why there was one. Then she usually solved the problem straight away. She also referred to her earlier experience and exploited her extratextual knowledge to the fullest. There were hardly any signs of genuine insecurity. The problems which emerged in the advertisement task required more processing, and the subject returned to the problems on several occasions. The slogans in the source text elicited the kind of evaluations exemplified below:

(14) tää fiksu tapa (.) tää on siis se i-nyt se (2.0) juju tässä (.) ja varmaan (.) se kaikkein hankalin juttu (.) kääntää sitte englanniks tai (.) tehä jotain (.) jotain sen kanssa [this smart habit (.) this is then the (.) now the (2.0) point here (.) and probably (.) the most difficult one (.) to translate into English or (.) to do something (.) something with] 
(15) suositeltava suomalainen (5.0) se on inhottava tommonen alkusointu joka (tota) (4.0) jota ei varmasti pysty kääntämään (.) tai si-(.) siirtämään toiseen kieleen [suositeltava suomalainen (recommendable Finnish) (5.0) it's a nasty allitteration that (well) (4.0) that certainly can't be translated (.) or tr-(.) transferred into another language]

(16) just nää tämmöset iskulauseet on tavattoman hankalia kääntää kun niit ei (.) nimenomaa kun niitä kääntää (.) ei-äidinkieleensä ku niis- nïstä ei silleen voi olla ihan varma (2.0) kaiken kaikkiaankaa

[it's exactly this kind of slogans that are terribly difficult to translate because they cannot (.) especially when you translate them (.) into your non-native language when you (.) you can't be sure (2.0) anyway]

The above excerpts indicate a more negative approach to problems in the non-routine task. Leena's comments were more pessimistic and occasionally almost desperate. From time to time she appeared to wonder whether she would find an appropriate solution at all.

Greater confidence in the routine process was also shown by the fact that Leena started to translate the routine text straight away after reading it through once, whereas she needed more time for getting acquainted with the non-routine assignment. She also regarded the non-routine translation as a draft that should be proofread by a native-speaker before being published but seemed to think that the routine text could be published as such. In one of the follow-up interviews that were carried out after each experimental session the subject mentioned that in a non-routine task there was always a feeling of uncertainty no matter how 'easy' the source text seemed.

All in all the evaluations found in the protocols revealed affective differences between routine and non-routine professional translation processes. The affective differences also seemed to account for the quality of the products.

In these experiments Francis was the only subject who voiced evaluations about himself as a translator in general and in relation to the task at hand. He did not like the text and the ideology it represented, as his comment in example 17 shows. He also mocked some of its stylistic choices, such as the use of the word osaaminen (knowhow) in example 18 .

(17) no (.) en mä usko että tämä on kovin vaikea teksti mutta (.) vastenmielinen se on (.) nïn (.) mustavalkoinen maailmankuva

[well (.) I don't think this is a very difficult text but (.) it certainly is unpleasant (.) such a (.) black and white world view]

(18) osaaminen (.) se on sana joka pitäis (.) kieltää

[osaaminen (.) that's a word that should be (.) forbidden]

In spite of his dislike of the text, Francis took the task seriously. For example, he spent 2.5 hours on the task and turned out a protocol of 20 pages, while Hanna spent two hours and turned out a protocol of 12 pages. Kari's figures were 1.5 hours and 11 pages. Francis verbalised 24 items about the source text and the translation task, whereas Hanna verbalised 13 and Kari only 4 such items. Francis's conscious analysis of the task was more detailed than the other two subjects'. There were some concepts to which he reverted on several occasions. One of these was kilpailulaki (which literally means competition law), which he evaluated as a "central concept" at an early stage of his protocol. He also commented on the linguistic requirements of the task, as shown by example 19 .

(19) voihan nenä (9.0) no en tarvitse pyrkiä ihan täydellisen (.) luontevaan englantïn koska tää (.) tiedetään et se on (4.0) käännös (.) käännös ja se (7.0) ja se on vain esimerkkiaineiston sisällä [oh heck (9.0) but I don't have to aim at a perfectly (.) natural English format as this is (.) as it will be known that it's a (4.0) translation (.) translation and that it (7.0) belongs to a corpus of sample texts] 
Francis had a clear picture of the task and he carried out a thorough and knowledgeable analysis of the text, but he nevertheless expressed uncertainty about his own ability to do the job. He voiced as many as 14 evaluations about himself, most of which were negative. Examples of self-evaluations are given below:

(20) olen vähän sellanen (.) lineaarinen kääntäjä

[I'm a somewhat (.) linear translator]

(21) en mä osaa kääntää ollenkaan

[I cannot translate at all]

(22) en tiedä mitä (4.0) hh.hh taloustekstissä on ne (.) tavalliset (.) sanankäänteet

[I don't know what (4.0) hh.hh in an economic text are the (.) routine expressions of (.) jargon]

(23) osoitan että en osaa tehdä sitä mitä näennäisesti opetan (4.0) on helpompi korjata jonkun toisen

[I show that I cannot do what I seem to be teaching (4.0) it's easier to correct somebody else's (work)]

(24) en edes ymmärrä englantia tarpeeksi hyvin

[I don't even understand English well enough]

(25) ohhoo minä (.) kirjoitan ihan kuin (.) talousmiehenä

[oh boy I'm (.) writing like (.) an economist]

Hanna and Kari did not verbalise self-evaluations, which in itself can be seen as an indication of security and confidence: they knew how to go about the task, and thus selfevaluation was not relevant for them. Moreover, their evaluations about the task as well as their individual variant choices bear evidence about confidence. The following examples will give an idea about the way they approached the task. Examples 26-27 are from Hanna and 28-29 from Kari.

(26) tää on hyvin (.) vetoaa sanoisin ihan vetoomuskeskeinen teksti ja onneks nää hh.hh lauseet tai niiku nyt tietysti (.) yleensä (.) tämäntyyppisessä (.) varmaan on niin ne on (.) lyhyitä ja hyvin iskeviä (.) tämmönen tietynlainen staccato (.) rytmi tässä ehkä se pitäs saada (.) siirtymään englantiinkin (.) ja sit toisaalta täss on semmonen saarnan ote (.) ehkä suomalaisille pitää just näistä asioista saarnata (.) että kilpailu on terveellistä eikä (.) eikä mikään paheksuttava asia (.) katotaas nyt sitte jos tähän sais tota vetoomusta ja (.) ja (.) opetustakin mukaan

[this is very (.) it appeals I would say quite an appeal-oriented text and luckily these hh.hh sentences or like of course (.) normally (.) in this kind of (.) so they probably are (.) short and very straightforward (.) a kind of staccato (.) rhythm here perhaps it should be (.) transferred to English as well (.) and then on the other hand there's a kind of sermonlike approach here (.) perhaps Finns need preaching about these things (.) that competition is healthy rather than (.) than a bad thing (.) lets see then if it is possible to get the appeal expressed here and (.) and (.) a lesson as well]

(27) nää on (.) kï̈nostavia nää joissa .hh jälkiliitteellä viitataan (.) edeltävään tekstiin

[these are (.) interesting these where .hh there's a clitic particle conveying (.) a reference to previous text]

(28) ei hirmusen vaikeelta näytä sanastollisesti noin ensimmäiseltä lukemalta (.) yleiskielinen teksti

[doesn't look terribly difficult vocabularywise at the first reading (.) a non-specialist text]

(29) Advanced Learner's (.) no tässä nyt ei kyllä paljoa ole

[Advanced Learner's (.) this certainly does not have a lot to say]

Hanna classified the text as appeal-oriented and sermonlike and decided that these qualities were also to be present in her translation. Kari's few comments on the task as a whole related to vocabulary and the translation aids at hand. Perhaps the fact that Hanna and Kari worked as freelance translators and not only as teachers of translation gave them a professional identity which enabled them to approach new tasks with confidence: they 
knew from experience that they could solve translational problems and that there was no need to panic. Francis had less experience of professional translation and may have felt threatened by the situation in which his own skills were exposed. This difference in the translators' professional self-image, however, was not reflected on the quality of their products. The three translations were all appropriate to serve the purpose they were designed for.

\section{TOWARDS UNDERSTANDING SUBJECTIVE THEORIES OF TRANSLATION}

As was pointed out earlier, instances of variant choice elicited a rich data of evaluations which made it possible for us to get a glimpse at the implicit theories of translation which each of our subjects had. We begin by giving examples of Leena's "theory statements" in the routine task:

(30) jos nyt ihan oltas virallisia siihen tulis se nimi suomeks plus sitte selitys mutta mutta (2.0) kuulostaa kyllä aika hurjalta (.) täss esitteessä sit on paljon muutaki tämmösiä (.) lomakeskuksia koko esite nää (.) ei näitä vois ei näitä suomeks jätetä (.) lomaliiton lomakeskukset joo sulkava holiday centre (.) se suomalainen jätetään pois siitä kokonaan (.) suomenkielinen (.) ku se on vielä sitte tommonen ihan (.) käännettävissä oleva

[to be official you should have the name in Finnish plus an explanation in English but but (2.0) it sounds very strange (.) in this brochure there are quite a number of other (.) holiday centres the whole brochure (.) no you don't have these in Finnish (.) the holiday centres of Lomaliitto yeah SULKAVA HOLIDAY CENTRE (.) the Finnish attribution will be left out completely (.) the Finnish (.) as this happens to be quite readily (.) translatable]

(31) monia ulottuvuuksia excellent onks se nïnku lïan (.) mut ei nää nää on yleensä semmosia et nää voi (1.0) suht vapaasti kääntää kun se vaan kuulostaa kaunïlta

[many opportunities EXCELLENT is it somehow too (.) but these things can usually be quite freely translated as long as it just sounds pretty]

(32) no phh no en tiiä (.) ehkä pitäs siihen lisätä se boat cruise kuitenki se (.) cruise ei sit välttämättä sano (1.0) anna täyttä kuvaa koko (.) koko tilanteesta (.) tästä meïjän järvi (.) järvikulttuurista

[well phh I don't know (.) maybe I should add the BOAT CRUISE here anyway the (.) CRUISE doesn't necessarily say (1.0) doesn't describe very well the whole (.) the whole situation (.) our lake (.) lake culture]

(33) ehkä se on varminta kuitenki panna one to two eikä single or twin rooms (3.0) tää on nii joo (.) ei siinä ainakaa jää kiinni väärästä informaation antamisesta

[maybe it's safest to say ONE TO TWO instead of SINGLE OR TWIN ROOMS (3.0) this is so yeah.(.) at least you won't be blamed for giving wrong information]

(34) mut mites (3.0) tietyst sinne vois lisätä you may visit savonlinna with its opera festival (7.0) um (1.0) which is only forty kilometres away (3.0) sitten ne ois niiku tavallaan (.) listattu kaikki nää (1.0) kaikki nää monipuoliset mahdollisuudet (.) sit nïss ois myös tämmönen tietty sidoksisuus täs-(.) tän-(.) tän pätkän välillä (.) tai kesken

[but how (3.0) of course I could add YOU MAY VISIT SAVONLINNA WITH ITS OPERA FESTIVAL (7.0) um (1.0) WHICH IS ONLY FORTY KILOMETRES AWAY (3.0) then they would be in a way (.) all listed these versatile possibilities (.) then there would also be some kind of coherence he-(.) thi-(.) between this section (.) or in it]

(35) mitä varte ne nyt mainostaa itteensä oopperalla kun ne nyt on kuitenki Sulkavalla (2.0) mut sit jos ne ehottomasti haluu sen süihe ni emmä tiiä välttämättä mä en sitte saa sitä mennä poistamaankaa sieltä

[why do they advertise themselves with the opera now although they are in Sulkava (2.0) but then again if they really want to have it here I don't know I probably can't leave it out either]

Leena knew exactly what was done and what not in translating travel brochures. She pointed out that it was legitimate and advisable to translate quite freely in order to 
make the translation sound fluent and pretty. Yet she thought that it was not allowed to deviate too much from the original because the information in the brochure must be absolutely correct and not misleading. Leena emphasized the design of the text as a whole and paid attention to the coherence of the translation. She also added some items to the translation in order to better describe the images and impressions that she thought should be conveyed to the readers. In the following there are examples of "theory statements" in Leena's non-routine process:

(36) ei mut ei se oo luontevaa sanoo niin päin mun mielest täss pitäs olla ensiks tää Xylifresh [no but it's not natural to say it that way I think I should start with this Xylifresh]

(37) mut sit se ei oo kuitenkaan se ei oo minku samalla tav'alla (1.0) sitä (.) siihen (.) et se on vaan sitten se tuote eikä (.) cikä tapa (.) se ei ehkä vetoa samalla tavalla (6.0) kuitenkaan kun toi toi (.) jos siinä on se tapa

[but then it is not in the same way (1.0) it (.) there (.) then it's just the product and not (.) not the habit (.) maybe it doesn't appeal the same way (6.0) as this this (.) if there is the habit]

(38) sehä on just silleen niiku tossaki (vaikkei se nyt) välttämättä tietyst tarvii olla niin tohon alkutekstiin tukeutuu mutta kun sen kerran pystyy (.) tekemään melkeen samalla tavalla niin miksei (.) miks ruveta konstailemaan sitten muuten ku tää on ihan (.) sujuvaa ja (.) idiomaattista ja (.) tehokasta

[it's exactly as in the original (although it doesn't) necessarily have to be just the same but now that you can (.) do it almost the same way so why not (.) why make it too complicated as this is quite (.) fluent and (.) idiomatic and (.) effective]

Leena emphasized that the translation must be clear, natural and precise. She stressed that the translation should appeal to the readers the same way as the original. It seems that she tried to stay closer to the source text than in the brochure task. However, professionality showed also in the advertisement task in that Leena paid a lot of attention to the style of the translation, for example. It can be assumed that experience in translating travel brochures helped her in translating the advertisement as well. On the other hand, one gets the impression that she was trying to apply her travel brochure routines to the advertisement task, with the consequence that she ended up processing the text instead of writing a text of her own.

The number of "theory statements" for Hanna was 28, while it was as high as 60 for Kari and Francis. The following examples will give an idea of the kinds of expressions included in this category. Hanna was searching for a suitable term to convey the idea of 'price cartels' (hintakartellit), and she found the entry 'price agreement' in a dictionary, and then voiced the evaluation as in example 39 . She reverted to this point later in her protocol, and voiced the evaluation shown in example 40.

(39) hintakartelli tääll on tämmöne ku price agreement se kuulostaa vähän liian kiltiltä (1.0) of cartels panen siihe pelkästään ton cartel (.) todennäkösesti (2.0) cartel]

[price cartel what they have here is PRICE AGREEMENT it sounds a little bit too pleasant (1.0) OF CARTELS I will just put CARTEL (.) probably (2.0) CARTEL]

(40) the price (types) price agreements (types) of (.) äsh price se on niin kiltti toi price agreement (.) sehän on nïn myönteisen tuntunen (types) ei mitään myönteistä tähän nyt (.) the trusts (types) of various: aa äsh tuoll oli just se various (pas-) cartels (11.0) the trusts of (.) $\mathrm{mm}$ (types) many in-dust-ries industries (.) (types) will have to go (.) pannaa tähä näin kansanomasesti

[THE PRICE (types) PRICE AGREEMENTS (types) OF (.) äsh PRICE it is so pleasant that PRICE AGREEMENT (.) it is so favourable (types) we want nothing favourable here now (.) THE TRUSTS (types) OF VARIOUS: aa äsh I just had this VARIOUS (PAS-) CARTELS (11.0) THE TRUSTS OF (.) mm (types) MANY IN-DUST-RIES INDUSTRIES (.) (types) WILL HAVE TO GO (.) that's the pedestrian way we will put it] 
These examples show that Hanna discarded a translation variant as "too pleasant"; she did not want vocabulary which would have given an impression that the text took a favourable stand to constraints on competition. The extracts from Hanna's protocol below also contain evaluative expressions which illustrate how she pictured the target text she was producing.

(41) voiskohan siinä olla jotain komeampaa (.) the legislation tottakai joo [could it be someting more impressive (.) THE LEGISLATION yes of course]

(42) landed (.) found herself aaa oisko se juhlavampi [LANDED (.) FOUND HERSELF aaa would that be more festive]

(43) tuleekoha täst mitää selvää (.) (reads) (1)) powers of the various (.) spheres of interest (.) kyl se on laihan tuntunen (.) en tiiä ymmärtääkö englantilainen tosta nyt mitään

[I wonder if this makes any sense (.) (reads) (O) POWERS OF THE VARIOUS (.) SPHERES OF INTEREST (.) it does look lean (.) I don't know if an English person will understand it at all]

(44) ja sitte pannaas (types) and not a moment (.) too soon (.) oikee tämmönen saarnan loppu (.) not a moment too soon aa (1.0) for (types) in (.) alussa niin in January (types) se vois olla iskevämpi (tuo) January 1993 (.) we (.) ought to (.) know (.) mitä how to do it (types) täähän on puhekielen omanen (.) olisi osattava joo (.) noin

[and then lets put (types) AND NOT A MOMENT (.) TOO SOON (.) an end to a sermon that's what it is (.) NOT A MOMENT TOO SOON aa (1.0) FOR (types) IN (.) at the beginning yes IN JANUARY (types) it could be more accurate (this) JANUARY 1993 (.) WE (.) OUGHT TO (.) KNOW (.) what HOW TO DO IT (types) yeah this is spoken-like alright (.) ought to know yes (.) that's it]

(45) later events have proved this (.) events ei mitää events vaan development aah (.) se on tarpeeksi semmonen löysä- events on vähä täsmällisempi (types) later developments (types) ei oikeestaan tarkota mitää

[LATER EVENTS HAVE PROVED THIS (.) EVENTS no EVENTS here but DEVELOPMENT aah (.) it is sufficiently kind of loose- EVENTS is somewhat more accurate (types) LATER DEVELOPMENTS (types) does not mean anything really]

(46) indicates that even (1.0) the Finnish authorities have acknowledged the harmful effects of various cartels (.) tää tuntuu niin lapselliselta hh.

[INDICATES THAT EVEN (1.0) THE FINNISH AUTHORITIES HAVE ACKNOWLEDGED THE HARMFUL EFFECTS OF VARIOUS CARTELS $($.$) this feels so naive hh.]$

The evaluations extracted from Hanna's protocol show that she was systematically working towards the kind of target text which she had pictured for herself to begin with: the text was to be sermonlike, impressive, strong and elegant rather than naive, lean or clumsy; it was to be intelligible, accurate, festive but not stiff; it should have a curt staccato rhythm; occasionally a "loose" expression was allowed rather than an accurate one.

Below are some of the numerous evaluative expressions which were identified in Kari's protocol in the context of variant choice. These are the "theory statements" which reflect the qualities that Kari wanted to have in the target text that he was producing.

(47) sitten tuosson tommonen ongelma (.) kilpailulait ja eurolait (2.0) nyt tietysti olis (.) olis mukava jos ei tarvitsis toistaa sanaa laws

[then there's a problem (.) competition laws and eurolaws (2.0) now of course it would be (.) would be fine if one did not have to repeat the word LAWS]

(48) kuullostaaks tää vähän (.) turhan simppeliltä

[does this sound a little bit (.) overly simplistic]

(49) tämänkin vois (.) vois ehkä sisällyttää tuohon ensimmäiseen lauseeseen (.) ettei tulis semmosta (.) ikävää (.) toistoa

[this could (.) could perhaps be integrated in the first sentence (.) to avoid (.) unpleasant (.) repetition] 
(50) no jaa nyt se näyttää vähän (.) vähän liian simppeliltä tuo (1.0) liitos ensimmäisen ja toisen lauseen välillä eli (.) mä luulen että jotakin paddingiä mun pitäis (.) pitäis laittaa tuohon (.) these (.) doubts elikkä (.) ehkä the doubts voiced tai jotain tämmöstä (4.0) (types) ja (2.0) mmh (2.0) (types) ja sit vielä joku sana lisää .hh (4.0) tai (.) fraasi ehkä (.) mä nyt katon miltä in fact näyttäs tossa (types) (.) have in fact been borne out in practice

[well then now it looks a bit (.) a bit too simplistic this (1.0) conjunction between the first and the second sentence in other words $I$ think that some padding is needed (.) is needed there (.) THESE DOUBTS or (.) perhaps THE DOUBTS VOICED or something like that (4.0) (types) and (2.0) mmh (2.0)(types) and then one more word .hh (4.0) or (.) a phrase perhaps (.) I'll look how IN FACT would look there (types)(.) HAVE IN FACT BEEN BORNE OUT IN PRACTICE]

(51) coming competition laws alkaa (1.0) samannäköisesti (.) coming competition (.) siinä pitäis vähän vari- varioida kuulostas niinko foneettisesti mukavammalta

[COMING COMPETITION LAWS begins (1.0) the same way (.) COMING COMPETITION (.) we need a bit vari- variation there it would sound better phonetically]

(52) ja sitten s-genetiivi vai of-rakenne .hh (2.0) $\mathrm{mm} \mathrm{mm}$ ehkä ihan rytmisistä syistä nïn ehkä of-rakenne

[and then s-genitive or OF-construction .hh (2.0) $\mathrm{mm} \mathrm{mm}$ perhaps simply for rhythmic reasons the $\mathrm{OF}$-construction]

(53) vai pitäskö vähän koristella (.) have learned the true meaning of the word (7.0) no se (.) ehkä tuo pitempi kuulostas (.) niinku (.) tasapainosemmalta

[or should I decorate it a little (.) HAVE LEARNED THE TRUE MEANING OF THE WORD (7.0) well that (.) perhaps the longer expression would sound (.) like (.) more balanced]

(54) tässä nyt sitten vois (2.0) yrittää keksiä jotain (4.0) jotain tyylikkäämpää kuin (.) pelkkä least (7.0) hh.ehh (5.0) mhh mites olis (.) slightest hint of something (looks up) (7.0) mut siinon vähä umm (.) slightest ei ehkä oikein sovi taas (.) hint-substantiivin kanssa yhteen [there again I should (2.0) try to invent something (4.0) something more elegant than (.) just LEAST (7.0) hh.ehh (5.0) $\mathrm{mhh}$ how would it sound (.) SLIGHTEST HINT OF SOMETHING (looks up) (7.0) but that is a little umm (.) SLIGHTEST might not go together with (.) the noun HINT]

The evaluations extracted from Kari's protocol show that he aimed at a target text which sounds good, is not repetitive or simplistic, proceeds coherently from one sentence to the next, is phonetically and rhythmically acceptable and well-balanced.

Francis also produced a great number of "theory statements" which reflect the profile of the text he was aiming at. Below are some examples.

(55) to implement laws (.) accept pass laws hh.hh tää ei ole niin institutionaalisesti (.) tarkkaa vaan (4.0) miksei new fair competition laws

[TO IMPLEMENT LAWS (.) ACCEPT PASS LAWS hh.hh this does not have to be institutionally accurate but (4.0) why not new FAIR COMPETITION LAWS]

(56) mut ulkomaalaiselle se voisi olla tärkeää tietää että nää on niitä ensimmäisiä [but for a foreigner it might be important to know that these are among the first]

(57) Finland's present fair competition laws (.) its first (.) joo (.) sitten ei tarvitse relatiivilause vaan ihan mikä se on (.) apposatiivi vai (.) (writes) its first (.) are only three years old (.) joo tuo on aika (.) aika tyylikäs vähän kuin New York Timesia

[FINLAND'S PRESENT FAIR COMPETITION LAWS (.) ITS FIRST (.) yes (.) yes (.) then we won't need a relative clause but just what is it (.) an appositive or (.) (writes) ITS FIRST (.) ARE ONLY THREE YEARS OLD (.) yeah that's quite (.) quite elegant somewhat like the New York Times]

(58) are only three year old and were initially (.) thought to be toothless (.) no tuo on hyvä [ARE ONLY THREE YEARS OLD AND WERE INITIALLY (.) THOUGHT TO BE TOOTHLESS (.) okay that's good] 
(59) the harmful effects of (.) joo (8.0) joo (8.0) joo no tuo on ainakin (.) englantia mutta (3.0) mutta tää kilpailulakien myötä (.) onks se kausaalinen vai (.) pelkästään (.) samaa aikaa [THE HARMFUL EFFECTS OF (.) yes (8.0) okay that's at least (.) English but (3.0) this kilpailulakien myötä ('with the competition laws') (.) is it causal or (.) merely (.) simultaneous]

(60) rakenteen takia (4.0) in respect of se on niin finglish

[rakenteen takia (4.0) IN RESPECT OF that's so Finglish]

(61) mä luulen että laws on fair competition ei ole sama kuin kilpailu laws on competitive practices (.) fair competition on sitten tietynlainen että se (.) competitive practices on on suorempi

II think that LAWS ON FAIR COMPETITION is not the same as LAWS ON COMPETITIVE PRACTICES (.) FAIR COMPETITION is then of a particular kind so that this (.) COMPETITIVE PRACTICES is more straightforward]

(62) liian monta lyhyitä lauseita (.) kuulostaa simppeliltä toisaalta ehkä se ei ole vain minun tyyli (mutta) ehkä se on hyvä

[too many short sentences (.) sounds simplistic on the other hand perhaps it just isn't my style but perhaps its good]

Francis aimed at a text in which the language was English and not "Finglish." Also, the text was not to be repetitive or clumsy. He evaluated the style of the text he had produced as simplistic and not his own, because there were "too many short sentences," but he hesitantly left it unchanged. His "theory statements" contain a great proportion of evaluations which relate to accuracy of interpretation, whereas Kari's and Hanna's "theories" were mainly focussed on the style of the target text. On the other hand Francis also complimented himself on some stylistically elegant and "professional" solutions. It will be remembered that Leena's protocol of the non-routine task also contained items which were interpreted as self-encouragement.

\section{CONCLUSION}

As evaluation analysis has not so far been systematically applied to other thinkaloud data, the results of the present study must be regarded as tentative. However, some general conclusions can perhaps be made even at this early stage. One of these conclusions is that there seems to be a positive relation between confidence and translation quality. If the circumstances enhance the translator's feeling of security, she is more likely to assume the role of a communicator rather than that of a mere text processor. Professional experience and expertise obviously back up confidence. It seems, however, that lack of confidence can be "compensated for" by sheer academic interest and a motivation to do the job well, as we saw in Francis's case.

Those factors which undermine professional confidence and the translator's selfimage are obviously very complex and need research efforts in their own right. The present study shows that a change of the task from routine to non-routine type is one of those factors which have an undermining effect. There is every indication that Leena's translational proficiency was not fully exploited in the advertisement task. Her performance would probably have been better, if she had dared to liberate herself from the boundaries of the source text and to orient herself afresh to the preferences of international readers, instead of copying her routines of brochure translation. It is possible that the experimental situation elicited her "conservative" behaviour. Both tasks were referred to as translation tasks, since it was not possible to spoonfeed the idea that the translator was indeed to take responsibility for creating a publishable advertisement. Thus the subject did not assume responsibility as an author. If she had done this, she could have legitimately insisted on expert help to carry out the job. 
Francis, Hanna and Kari got a task which did not require a radical re-orientation. It was also a kind of task which is fairly typical in the translation school, and in that sense it might have appeared like a routine task for the subjects. Francis was the only subject who explicitly verbalised his conception of what the task required. Hanna mentioned that the source text was an appealing sermon and decided to try and maintain the same kind of appeal in the target text. She did not give reasons for this decision, however. Kari's conception about the requirements of the task as a whole was not verbalised at all, but this does not mean that he did not have a global conception. Irrespective of the implicitness of their verbalisations, however, the subjects produced texts which fulfilled the requirements of the task. It is possible that the orientation to "correct" task performance was automatic and therefore not verbalised.

Whereas the verbalisations about the task as a whole were scarce, those about single instances of variant choice provided a very rich data, and this was one of the starting points for our present research. Our subjects produced a range of quality criteria which guided them in their translational decisions. Some criteria were shared by the subjects, while others were individual or idiosyncratic. This data made it possible for us to get a glimpse at the theories which each of the subjects had. It seems that there is no single profile of a successful process but many, as has been established in previous research as well (e.g. Königs 1991: 137). Thus the challenge which faces the schools of translation is that they should create such circumstances which will give the individual students an opportunity to develop a positive professional self-image and confidence in their work. This can be achieved by transition from teacher-centred translation classes towards individualized projects which enable the students to accumulate experience of success in those areas where they have talent and genuine expertise.

Note

1. In fact the excerpts from the TAP's in House's (1988) article provide interesting data for evaluation analysis: the evaluations voiced by the subjects seem to reflect their self-image as translators.

\section{REFERENCES}

ETZIONI, A. (1988) "Normative - Affective Factors: Toward a New Decision-making Model", Journal of Economic Psychology, 9, pp. 125-150.

HALLIDAY, M. A. K., GIBBONS, J. and H. NICHOLAS (Eds) (1990): Learning, Keeping and Using Language, Amsterdam/Philadelphia, John Benjamins.

HOUSE, J. (1988): "Talking to Oneself or Thinking with Others? On Using Different Thinking-Aloud Methods in Translation", Fremdsprachen lehren und lernen, 17, pp. 84-98.

IWASAKI, E. (Ed.) (1991): Begegnung mit dem "Fremden". Grenzen - Traditionen - Vergleiche. Akten des VIII Internationalen Germanisten-Kongresses, Tokyo 1990, München, Iudicium.

JÄÄSKELÄINEN, R. (1990): Features of Successful Translation Processes: A Think-Aloud Protocol Study, Unpublished licentiate thesis, University of Joensuu, Savonlinna School of Translation Studies.

JÄÄSKELÄINEN, R. (in this volume): "Hard Work will Bear Beautiful Fruit. A Comparison of Two ThinkAloud Protocol Studies".

KUSSMAUL, P. (1991): "Creativity in the Translation Process: Empirical Approaches", van Leuven-Zwart and Naaijkens (Eds), Translation Studies: The State of the Art. Proceedings from the First James S. Holmes Symposium on Translation Studies, Amsterdam, Rodopi, pp. 91-101.

KÖNIGS, F. G. (1991): "Dem Übersetzen den Prozess machen? Psycholinguistische Überlegungen zum Übersetzen und ihre didaktischen Konsequenzen", Iwasaki (Ed.), Begegnung mit dem "Fremden". Grenzen Traditionen - Vergleiche. Akten des VIII Internationalen Germanisten-Kongresses, Tokyo I990, München, Iudicium, Bd. 5, pp. 132-142.

LAUKKANEN, J. (1993): Routine vs. Non-routine Processes in Translation: A Think-Aloud Protocol Study, an unpublished M.A. thesis, University of Joensuu, Savonlinna School of Translation Studies.

LAUKKANEN, J. (in press): "Affective Factors in Translation Process".

LEFEVERE, A. (1992): Translating Literature. Practice and Theory in a Comparative Literature Context, New York, The Modern Language Association of America. 
LEWANDOWSKA-TOMASZCZYK, B. and M. THELEN (Eds) (1992): Translation and Meaning, Part 2, Rijkshogeschool Maastricht, Faculty of Translation and Interpreting.

MOSSOP, B. (1983): "The Translator as a Rapporteur: A Concept for Training and Self-Improvement", Meta, 28-3, pp. 244-277.

SCHWENK, C. (1984): “Cognitive Simplification Processes in Strategic Decision-making", Strategic Management Journal, 5, pp. 111-128.

TIRKKONEN-CONDIT, S. (1990): "Professional vs, Non-Professional Translation: A Think-Aloud Protocol Study", Halliday, Gibbons and Nicholas (Eds), Learning, Keeping and Using Language, Amsterdam/Philadelphia, John Benjamins, pp. 381-394.

TIRKKONEN-CONDIT, S. (1992): "The Interaction of World Knowledge and Linguistic Knowledge in the Processes of Translation. A Think-aloud Protocol Study", Lewandowska-Tomaszczyk and Thelen (Eds), Translation and Meaning, Part 2, Rijkshogeschool Maastricht, Faculty of Translation and Interpreting, pp. 433-440.

VAN LEUVEN-ZWART, K. M. and T. NAAIJKENS (Eds) (1991): Translation Studies: The State of the Art. Proceedings from the First James S. Holmes Symposium on Transiation Studies, Amsterdam, Rodopi.

WILSS, W. (in press): "Translation as Decision-making", TARGET.

APPENDIX 1. Leena's routine translation.

\section{SULKAVA HOLIDAY CENTRE}

58700 SULKAVA Tel. (957) 71761

\section{Versatile holiday activities ranging from opera to regatta}

The Sulkava Holiday Centre, situated amidst the magnificent landscape around the Vilkaharju ridge, offers plenty of opportunities for a holiday-maker. Savonlinna with its Opera Festival is only $40 \mathrm{~km}$ away. Evening boat cruises on lake Saimaa depart from the jetty of the holiday centre. Or you can try trolling by night or fishing on the nearby trout pond. You'll find a variety of pastimes, including organised activities, for your entire holiday. And if you are looking for something special, visit the Sulkava Rowing Regatta at the second weekend in July and see the races between traditional church-boats (i.e. long rowing-boats).

There is also a lively pub/restaurant providing dancing and entertainment, which is extremely popular among the locals, too.

Location: In the rural district of Sulkava, $40 \mathrm{~km}$ from Savonlinna, $80 \mathrm{~km}$ from Imatra.

Accommodation and restaurant facilities: 20 single or twin rooms in holiday homes, 24 twin rooms in linked villas, 20 twin rooms in semi-detached cabins. All rooms with WC, shower, fridge, coffee-maker, clockradio. Sauna available free of charge 5 times a week.

Restaurant with comfortable terrace bar. Total capacity 350 seats. Fully-licensed. Non-smoking café. Unlimited use of the 'Ilola' lounge for residents.

Recreational facilities: Excellent beach. Good hiking facilities in the pine woods. Rowing-boats, canoes, church-boat (long rowing-boat), pedal boats, sailboards. Crazy-golf, table tennis, badminton and volleyball courts, bicycles. Children's play area. Holiday coordinator's services. Good opportunities for fishing as well as for berry-picking and mushrooming.

\section{APPENDIX 2. Leena's non-routine translation.}

\section{RECOMMENDED. FROM FINLAND.}

XyliFresh, the first xylitol chewing gum in the world, is a Finnish invention which revolutionizes the consumption habits of gum. XyliFresh contributes to the health of your teeth.

Today XyliFresh is the best-selling confection in Finland. Its success is the result of close cooperation between Finnish product development and dental research.

XyliFresh was the first chewing gum in Finland, Sweden, Norway and Iceland to receive a xylitol recommendation by the respective dentists' associations.

The smart Finnish habit is now spreading everywhere.

The smart habit Prevent the acid attack

Leaf

- for xylitol products

APPENDIX 3. Experimenter's translation of the editorial.

COMPETITION MUST BE LEARNED

(I-II) Although companies try to avoid competition, it is in the interest of the economy as a whole that viable competition should be secured by legislation. 
(III) Against this background it is necessary that the laws on competitive practices are now being tightened up in Finland. There is much less competition here than in western Europe which we are going to be part of in a year's time. Finland's new competition laws can in actual fact (1) be considered our first European laws. They are relatively closely modelled on the

legislation prevailing within the EC and the EEA.

(IV) Finland's existing competition laws - our first - were passed only three years ago and were suspected to be toothless to begin with. In practice they have indeed(2) turned out to be insufficient. If they had not been tightened, we would have drifted into a situation in which firms would have been treated more leniently in the domestic market than in the international

arena.

(V) By passing the new laws Finland acknowledges the detrimental effects of price cartels also in this country. The price agreements in various industries will have to go. Competitive imports will be encouraged Yet for some reason monopolies are still cherished. This is difficult to explain, unless Finland still wants to protect its big state-owned companies or food monopolies. Also(3) the control of mergers is still lagging behind the rest of Europe. The argument that Finland is a small country which needs big companies is not wholly convincing. A small country has a vulnerable market structure.

(VI) As in Europe, the sanctions of the new laws are fines, which can rise to the millions of marks. The regulatory role of the Competitive Practices Commission will be enhanced when the lobbies represented on it are thrown out.

(VII) Our history of competition is short. Thus (4) it is no wonder that neither firms nor consumers have yet understood what it means. Firms think even the mildest price competition is too fierce. Consumers are baffled by different prices, or even deplore them, when they ought to applaud them. After all, differences in prices are the first sign of competition.

(VIII) The fact is that (5) competition in the domestic market is only just emerging in many sectors. The new laws on competitive practices will stimulate the process of learning, and in due course their effect will show in prices as well. And not a moment too soon, because by 1993 we should know how to cope. 